\title{
Canadian survey of reduction mammaplasty techniques
}

\author{
Michele M Carr DDS MD \\ Department of Otolaryngology, Dalhousie University, Halifax, Nova Scotia \\ Arnis Freiberg MD FRCSC \\ Department of Surgery, University of Toronto, Academic Aesthetic Surgery Service, \\ Toronto Hospital, Western Division, Toronto, Ontario
}

\begin{abstract}
MM Carr, A Freiberg. Canadian survey of reduction mammaplasty techniques. Can J Plast Surg 1995;3(4):199-201. Reduction mammaplasty has become an accepted surgical procedure in North American society. The purpose of this study was to determine the method used by Canadian plastic surgeons to perform this procedure. A survey was sent out to all members of the Canadian Society of Plastic Surgeons in the spring 1993 mailing which questioned them on various aspects of their technique. Response rate was $45 \%$ and surgeons did on average 4.6 reduction mammaplasties per month which were covered by provincial health insurance in $96 \%$ of cases. The most popular method overall was an inferior pedicle technique, used by $65 \%$ of surgeons. Most surgeons altered their procedure in special clinical situations such as small or very large reductions, ptotic breasts, tubular breasts, or second procedures.
\end{abstract}

Key Words: Canadian survey, Reduction mammaplasty, Surgical techniques

\section{Sondage canadien sur les techniques de réduction mammaire}

RÉSUMÉ: La réduction mammaire est une intervention chirurgicale désormais acceptée dans nos sociétés nord-américaines. Le but de cette étude était de déterminer quelle méthode utilisent surtout les chirurgiens-plasticiens au Canada. Un sondage a été envoyé à tous les membres de la Société canadienne des chirurgiens-plasticiens au printemps de 1993 pour les interroger au sujet de divers aspects de leurs techniques. Le taux de réponse a été de $45 \%$ et les chirurgiens effectuent en moyenne 4,6 réductions mammaires par mois, couvertes par le régime d'assurance-maladie provincial dans $95 \%$ des cas.La méthode la plus populaire, dans l'ensemble, est la technique du pédicule inférieur, utilisée par $65 \%$ des chirurgiens. La plupart d'entre eux modifient la technique en présence d'une situation clinique spéciale, comme dans le cas de réductions très légères ou très importantes, de ptose mammaire, de seins tubulaires ou de réintervention.

Reduction mammaplasty is a commonly performed operation in Canada today. There is a variety of procedures described to reduce breast size, and case series are described in the literature purportedly demonstrating the superiority of one method or 
another. Apart from this, other details of the surgical protocol are disputed in the literature from whether or not to use drains (1), to the need for blood transfusion (2). The purpose of this study was to find out how Canadian plastic surgeons performed reduction mammaplasty.

\section{METHOD}

A 22 item questionnaire was enclosed in the spring 1993 mailing to the 399 members of the Canadian Society of Plastic Surgeons. Questions established where the surgeon had trained, how long they had been in practice, and where they were currently working. They were asked which reduction mammaplasty technique they usually employed, and which they felt was optimal for a variety of clinical situations. Whether they modified the technique as it was described in the literature, and how much they enjoyed performing reduction mammaplasty, was included.

Data were analyzed using a Quattro Pro 5 spreadsheet and SPSS 3 software.

\section{RESULTS}

One hundred and seventy-eight responses were received for a response rate of $45 \%$, comparable to other surveys of this population (3). Of these, seven did not perform reduction mammaplasty and so did not complete the survey.

Eighty-eight per cent were Canadian trained, 26\% in Toronto and 25\% in Montreal, with the remainder trained all across Canada. Half had done fellowships but only three had done breast surgery fellowships. The younger surgeons (those with fewer than 10 years in practice) had done significantly more fellowships than those with more experience $(\mathrm{P}<0.05)$. The average number of years in practice was 14.5 , ranging from a few months to 36 years.

The average number of reduction mammaplasties per month for those who did them was 4.6, ranging from 0.1 to 20 . More experienced surgeons did significantly more; 5.28 per month for surgeons with more than 10 years experience versus 3.35 for those with less $(\mathrm{P}<0.05)$. This is estimated to be about 50 per year, or $7 \%$ of a surgeon's total number of procedures (based on an average of 750 procedures per year) (3).

Across the provinces there were differences in the number of years in practice and the number of reduction mammaplasties done and these in general had a direct correlation (Figure 1).

Reduction mammaplasty was covered by insurance in $96 \%$ of cases and this did not vary across the provinces.

\section{Techniques}

In the survey, nine well-known techniques were listed and respondents were asked to check their usual technique. These included amputation with free nipple graft (4), inferior pedicle, both Robbins (5) and DC Robertson technique (6), superior pedicle (7), central pedicle, Biesenberger type (8), Regnault 'B' (9), and Arié-Pitanguy (10), horizontal bipedicle (11), and vertical bipedicle $(12,13)$. The Robbins type of inferior pedicle technique (5) was most popular and cited as the primary technique of $65 \%$ of respondents. A further $9 \%$ used it in conjunction with another technique. The vertical bipedicle as described by McKissock was cited by $12 \%$ of the total, the second most popular technique $(12,13)$. More than one technique was listed by $12 \%$ as their usual, and 


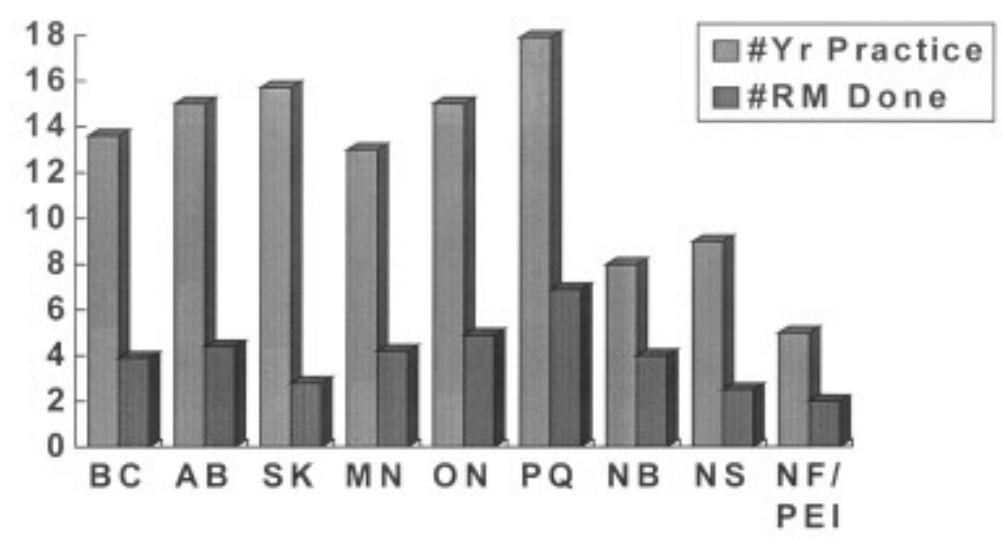

Figure 1) Canadian plastic surgeons: Number of years in practice and number of reduction mammaplasties per month across provinces

most of these included either Robbins or McKissock. All of those who employed amputation with free nipple graft used another technique as well. Half of respondents felt that they had personally modified their procedure.

Surgeons learned these techniques most frequently during their residency (47\%), or from journal articles (18\%) and conferences $(11 \%)$. The remainder used more than one source of information.

Seventy-nine per cent of surgeons felt that differing clinical situations warranted changing their approach. We asked about five specific types of cases, including small reductions, very large reductions, ptosis, tubular breast deformity, and secondary procedures.

For small reductions $40.5 \%$ felt that an inferior pedicle technique was most appropriate. Eighteen per cent preferred superior pedicle and $17 \%$ preferred the vertical bipedicle. Sixteen per cent used a central pedicle technique, most using a Regnault 'B' or Arié-Pitanguy.

For large reductions $72 \%$ preferred amputation combined with free nipple graft. Eighteen per cent still used an inferior pedicle technique (almost one third of these used a DC Robertson technique) and $8 \%$ used a vertical bipedicle.

Ptotic breasts were treated with an inferior pedicle technique by $42 \%$ of surgeons. About $15 \%$ chose vertical bipedicle and $15 \%$ chose central pedicle techniques. Superior pedicle, mastopexy and L technique (14) comprised a further $20 \%$.

There was little agreement on management of tubular deformity. One quarter preferred an inferior pedicle technique while $20 \%$ used a donut mastopexy. An implant associated with excision of redundant skin was used by $17 \%$. Ten per cent used a vertical bipedicle.

Second procedures were also handled by a variety of techniques. One third of respondents felt that the choice of technique depended on the initial one. Twenty per cent still preferred an inferior pedicle technique and $16 \%$ preferred each of vertical bipedicle and revision combined with free nipple graft. 
Surgeons were asked to mark how much they enjoyed performing reduction mammaplasty as compared to their other procedures on a six point scale from 0 , their least favourite procedure to 5 , their favourite. The average rank was 3.45 .

\section{DISCUSSION}

There is no single procedure to perform reduction mammaplasty in all types of breast hypertrophy (15). This is a difficult surgical problem, encompassing issues of neurovascular anatomy, three-dimensional shape, esthetics and symmetry (16). Twentyseven different procedures were named in this survey, suggesting that at least this number is currently in use in Canada today. These techniques have been described in the literature, each author building on previous successes and attempting to resolve persisting problems. Each major step has been accompanied by an explosion of minor modifications such that an article on this topic can be found monthly in at least one of the major plastic surgery journals. Some authors believe that the availability of many techniques improves the surgeon's ability to help women with macromastia (17).

Reduction mammaplasty affords the patient with symptomatic relief from macromastia (18) and is met with a high degree of satisfaction (19).

The popularity of inferior pedicle techniques is understandable since all degrees of reduction are possible and nipple viability and sensibility are reliable $(5,6,20,21)$. This technique allows areolar relocation along a greater distance than do superior pedicle techniques (22). Longterm results are stable over many years (23). In Canada, three quarters of plastic surgeons use this technique primarily.

A significant minority prefer the McKissock vertical bipedicle across a wide range of clinical situations. McKissock feels that his technique has wide application, including ptosis (12) but does not recommend it where more than $1 \mathrm{~kg}$ is expected to be resected from each breast or if the overall vertical flap length would exceed $35 \mathrm{~cm}$ (13). Folding of this potentially long pedicle can result in nipple ischemia (15).

The appropriate technique for specific clinical problems usually instigates debate in any group of plastic surgeons. Small reductions can be accomplished reliably with any pedicled technique. The originators of certain central pedicle techniques such as AriéPitanguy and the Regnault ' $\mathrm{B}$ ' recommend them for these types of cases $(9,10)$. Large reductions, usually defined as greater than $2500 \mathrm{~g}$ per breast, are the only situations where amputation with free nipple graft is widely advised $(13,15,22)$. This is a reliable and simple method useful when the patient is beyond nursing age, and does not consider nipple sensation to be important $(22,24)$. Often these patients have reduced nipple sensation preoperatively (22).

Ptotic breasts, where the nipple falls below the inframammary crease, can be treated successfully by many techniques according to their proponents, including Robbins, Strombeck, McKissock, and Regnault $(5,9,12,15,25)$. Superior pedicles are felt to be inappropriate because superior transposition of the nipple-areolar complex is limited (15).

Tubular breasts are relatively uncommon and have a constricted breast base with glandular tissue forced into the areola $(24,26)$. Surgical goals include expansion of the base, reduction of the enlarged areola and flattening of the areola $(26,27)$. Donut mastopexy is useful to achieve the latter two of these (26). Central pedicle techniques including Biesenberger, Benelli 'round block' and Regnault 'B' also serve to reduce the 
elongated proportion of these breasts. Usually, tubular breasts are not hypertrophied and require augmentation combined with excision of redundant skin, via mastopexy or periareolar resection.

Reduction mammaplasty following relapse is a challenging problem since blood supply to the nipple may be altered depending on the type of flap originally used. Only one third of surgeons consider this fact before planning their procedure. Whether it is safe to cut the original pedicle is unknown at present. Free nipple graft is more likely to be used here to negate this consideration.

\section{CONCLUSION}

In general, Canadian plastic surgeons prefer an inferiorly based pedicle technique when doing reduction mammaplasty, but $80 \%$ will alter their technique in particular clinical situations.

\section{REFERENCES}

1. Cartotto RC, Levine R, Knowlton R, Fielding C. Reduction mammaplasty: To drain or not to drain? 46th Annual Meeting of the Canadian Society of Plastic Surgeons May 2730 1992, London, Ontario, p 29.

2. Clugston PA, Fitzpatrick DG, Kester DA, Folay B, Germann E. Autologous blood use in reduction mammaplasty: is it justified? Plast Reconstr Surg 1995;95:824-8.

3. Kerrigan C. Results of the survey of CSPS members. CSPS News 1994;5(1\&2):1,5.

4. Thorek M. Possibilities in the reconstruction of the human form. NY Med J 1922;58:572.

5. Robbins TH. A reduction mammaplasty with the areola-nipple based on an inferior dermal pedicle. Plast Reconstr Surg 1977;59:64-7.

6. Robertson DC. The technique of inferior flap mammaplasty. Plast Reconstr Surg 1967;40:372-7.

7. Cramer LM, Chong JK. Unipedicle cutaneous flap: areola-nipple transposition on an end-bearing superiorly based flap. In: Georgiade NG, ed. Reconstructive Breast Surgery. St Louis: CV Mosby Co, 1976: 143.

8. Biesenberger H. Eine neue methode der mammaplastik. Zentralbl Chir 1928;55:2382.

9. Regnault P. Breast reduction: B technique. Plast Reconstr Surg 1980;65: 840-5.

10. Pitanguy I. Surgical correction of breast hypertrophy. Br J Plast Surg 1967;20:78.

11. Skoog TA. A technique of breast reduction. Acta Chir Scand 1963;126:453.

12. McKissock PK. Reduction mammaplasty with a vertical dermal flap. Plast Reconstr Surg 1972;49:245-52.

13. McKissock PK. Color atlas of mammaplasty. New York: Thieme Medical Publishers Inc, 1991.

14. Born G. The 'L' reduction mammaplasty. Ann Plast Surg 1994;32:383-7.

15. Georgiade NG, Serafin D, Riefkohl R, Georgiade GS. Is there a reduction mammaplasty for 'all seasons'? Plast Reconstr Surg 1979;63:765-73.

16. McKissock PK. Reduction mammaplasty by the vertical bipedicle flap technique: rationale and results. Clin Plast Surg 1976;3:309-20.

17. Kurtay M. Standardization in reduction mammaplasty: a comparison of techniques. Plast Reconstr Surg 1993;92:960-7. 
18. Gonzalez F, Walton RL, Shafer B, Matory WE, Borah GL. Reduction mammaplasty improves symptoms of macromastia. Plast Reconstr Surg 1993;91:1270-6.

19. Hughes LA, Mahoney JL. Patient satisfaction with reduction mammaplasty: an early survey. Aesthetic Plast Surg 1993;17:345-9.

20. Courtiss EH, Goldwyn RM. Reduction mammaplasty by the inferior pedicle technique: an alternative to free nipple and areolar grafting for some macromastia or extreme ptosis. Plast Reconstr Surg 1977;59:500.

21. Sandsmark M, Amland PF, Abyholm F, Traaholt L. Reduction mammaplasty; a comparative study of the Orlando and Robbins methods in 292 patients. Scand J Plast Reconstr Surg Hand Surg 1992;26:203-9.

22. Bostwick III J. Aesthetic and reconstructive breast surgery. St Louis: CV Mosby Co, 1983.

23. Freiberg A, Carr MM. Reduction mammaplasty: position of the nipple-areolar complex after long-term follow-up. Can J Plast Surg 1994;2:117-20.

24. Letterman G, Schurter M. A history of reduction mammaplasty. In: Georgiade NG, Georgiade GS, Riefkohl R. Aesthetic Surgery of the Breast. Philadelphia: WB Saunders, 1990:161-9.

25. Strombeck JO. Mammaplasty: report of a new technique based on the two pedicle procedure. Br J Plast Surg 1960;13:79.

26. Rees TD, Aston S. The tuberous breast. Clin Plast Surg 1976;3:339.

27. Biggs TM, Humphreys DH. Augmentation mammaplasty. Grabb and Smith's Plastic Surgery, 4th edn. Boston: Little, Brown and Co, 1991:1145-56. 